\title{
The Lasting Effects of Crime: The Relationship of Discovered Methamphetamine Laboratories and Home Values
}

\author{
By \\ Joshua Congdon-Hohman \\ November 2011

\begin{abstract}
COLLEGE OF THE HOLY CROSS, DEPARTMENT OF ECONOMICS
FACULTY RESEARCH SERIES, PAPER NO. 11-14*
\end{abstract}

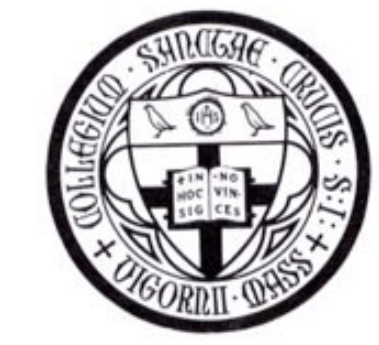 \\ Department of Economics \\ College of the Holy Cross \\ Box 45A \\ Worcester, Massachusetts 01610 \\ (508) 793-3362 (phone) \\ (508) 793-3708 (fax)
}

http://www.holycross.edu/departments/economics/website

*All papers in the Holy Cross Working Paper Series should be considered draft versions subject to future revision. Comments and suggestions are welcome. 


\title{
The Lasting Effects of Crime: The Relationship of Discovered Methamphetamine Laboratories and Home Values
}

\author{
By \\ Joshua Congdon-Hohman ${ }^{\dagger}$ \\ College of the Holy Cross
}

November 2011

\begin{abstract}
This study estimates a household's willingness to pay to avoid the stigma of crime while minimizing concerns of omitted variable bias. By assuming methamphetamine producers locate approximately at random within a narrowly defined neighborhood, this study is able to use hedonic estimation methods to estimate the impact of the discovery of a methamphetamine laboratory on the home values near that location. Specifically, the analysis designates those closest to the site as the treated, while those slightly farther away act as the comparison group. The discovery of a methamphetamine laboratory has a significant effect on the property values of those homes close to the location that peaks from six to 12 months after each lab's discovery. The estimates found in this study range from a decrease in sale prices of ten to nineteen percent in the year following a laboratory's discovery compared to the prices for homes that are farther away but still in the same neighborhood. Surprisingly, the impact does not appear to depend on intensity as both the discovery of a second lab and being very close to the discovered lab do not adversely impact home values.
\end{abstract}

JEL Classification Codes: H41, H76, K42, R32

Keywords: Location choice, crime valuation, methamphetamine, housing prices

* Thanks to Charlie Brown, Jeff Smith, Tom Buchmueller and David Albouy for their helpful guidance and support. Thanks also to the Summit County Fiscal Office, Ohio Department of Transportation, and Spatial and Numeric Data Services at the University of Michigan for providing data and technical support. Additional thanks to Robert Baumann, Kathy Kiel, and seminar participants at the College of the Holy Cross and Clark University for their helpful input. All errors and omissions are my own.

${ }^{\dagger}$ Department of Economics, Box 72A, College of the Holy Cross, Worcester, MA 016102395, 508-793-3673 (phone), 508-793-3708 (fax), jcongdon@ @olycross.edu 


\section{Introduction}

The effects of crime on property values have been a long-standing focus of economic research as they are one of the best measures available for the value people put on safety. The accuracy of high valuations found in early studies using cross-sectional data is questionable because of the problem of omitted variable bias. Specifically, crime is not randomly assigned to neighborhoods and it is likely correlated with unobservable qualities that may also be correlated with home values. In an attempt to minimize this source of bias, recent research on a number of localized events has begun identifying the difference in responses between those affected most and those who also live nearby but are not affected as intensely by the event in question. This approach has been identified in some studies as a "quasi-experimental

approach" because of the assumed random assignment of the location of an event within a narrowly defined neighborhood, even though the selection of the neighborhood is not assumed to be random. Using a similar approach, I will examine the difference in the effects of the discovery of a methamphetamine laboratory ("meth lab") in a neighborhood between those closest to the location and those slightly farther away. Though the discovery of the laboratory implies its closure, the discovery indicates the existence of crime in the neighborhood and may be a signal both to current and future residents that the neighborhood is less safe than others. By comparing the change in home sale prices after the discovery of a nearby laboratory to the changes in prices to other homes in the neighborhood that are slightly farther away, any difference in the changes can be interpreted as the value of avoiding the signal of crime, if not the valuation of crime itself.

This study will use a new proxy for general crime levels to assess an individual's willingness to pay to avoid a neighborhood that has been publicly associated with illicit activity. The discovery of methamphetamine labs has not been used in this way in previous literature and offers a unique opportunity to examine the impact of a sudden change in the perceived level of crime in a neighborhood. Unlike a home that is being used for drug use (a "crack house" or "drug den") or for prostitution which might be seen as a similar disamenity to 
neighbors, the existence of a meth lab is often unknown to its neighbors until it is raided by police ("busted") due to a lack of traffic or other signs of criminal activity. Two recent studies by Linden and Rockoff (2008) and Pope (2008) have focused on similar sudden increases in the perceived risk of crime by examining the arrival of a sex offender to a neighborhood. As with the approach used in this study in regards to the location of methamphetamine labs, the arrival of a sex offender is not considered globally random as offenders tend to locate in lower cost areas. Instead, the actual residence of the offender is considered random only within a small area (defined as 3/10 of a mile in Linden and Rockoff (2008), 2/10 of a mile in Pope (2008)). In other words, though it may not be random that the sex offender moved into a particular neighborhood, his location within that neighborhood can be considered a random choice in that it is made based on availability rather than qualities of the location (which are assumed to be similar throughout the neighborhood).

I find that the discovery of a methamphetamine laboratory has a significant impact on the property values of those homes close to the location that peaks between six to 12 months after the lab's discovery. In this study, the estimated decrease in sale prices ranges from ten to nineteen percent in the year following a laboratory's discovery compared to the prices for homes that are further away but in the same neighborhood (here defined as within a quarter of a mile of the discovered lab). Studies on the willingness of individuals to pay to avoid crime have found a range of values that are hard to compare based on the differences in types of crimes and the comparison groups being used. In an early work, Thaler (1978) found that areas with one standard deviation lower crime rate have three percent higher property values. A more recent study by Gibbons (2004) found that the same drop in the crime rate was associated with a ten percent increase in property values. ${ }^{1}$ In the research on sex-offender locations, Linden and Rockoff (2008) found that homes closest to the location of an arriving sex offender sell for four percent less than those homes slightly farther away while Pope (2008) finds a similar 2.3 percent drop but an immediate recovery to pre-offender

\footnotetext{
${ }^{1}$ Other research on the value of crime reduction includes Cullen and Levitt (1999), Katz et al. (2001), and Kuziemko and Levitt (2004)
} 
levels once the offender moves out of the area.

Less explored in the previous literature is how individuals respond to the intensity of risk. In this study, I examine whether the discovery of multiple labs in the vicinity of a home has an additional adverse effect on its sale price. Surprisingly, I find that it does not, which supports the theory that individuals either consider their neighborhood risky or not and do not differentiate based on the level of risk. Similarly, Pope (2008) found that the degree of a sex offenders crime (that is, some sex offenders were identified as "Predators" because of the severity of the crimes they committed) did not influence the level of the response. Similarly, I find that the impact of a lab's discovery is not monotonic as those who are closest to the discovered lab do not experience the highest adverse impact on their home values.very is not monotonic as those who are closest to the discovered lab do not experience the highest adverse impact on their home values.

In the next section, I will provide a basic overview of methamphetamine and its production in the United States. In Section 3, I will discuss the data used in this study while Section 4 presents the raw trends in the data. Section 5 describes the empirical methodology in greater detail. Section 6 presents the results of the primary specifications and addresses additional questions about the pattern and possible causes of the negative impact from the laboratory's discovery. Section 7 concludes.

\section{Overview}

The Office of National Drug Control Policy describes methamphetamine ("meth") as a "highly addictive central nervous system stimulant that can be injected, snorted, smoked, or ingested orally." ${ }^{2}$ Methamphetamine is different from other drugs in that it can be produced using easily accessible household goods and equipment. As a result, methamphetamine production sites are the most common clandestine drug laboratories found in the United States today. Large-scale domestic production has decreased in recent years due to restrictions on

\footnotetext{
${ }^{2}$ http://www.whitehousedrugpolicy.gov/drugfact/methamphetamine/methamphetamine_ff.html
} 
the sales of bulk amounts of the over-the-counter products that are precursors (i.e. raw materials) to methamphetamine production. ${ }^{3}$ Earlier economic research by Dobkin and Nicosia (2009) found that government efforts to reduce the supply of meth precursors had only temporary effects on the price and quality of methamphetamine available in the United States. The event they study was a large, 1995 DEA action that severely limited the distribution of wholesale amounts of meth precursors to large-scale clandestine labs. Though the authors are uncertain of the reason for the quick rebound of meth's purity and price, one reason may have been a shift to decentralized production that required less massive amounts of precursor drugs, such as home lab production that is examined in this paper. Nationally, methamphetamine laboratory seizures peaked in the years 2003 and $2004 .^{4}$

Methamphetamine laboratories ("meth labs") pose great risks to those who enter the premises and those who live nearby (Scott, n.d.). The mixing of the chemical precursors to meth is a highly volatile process and creates a risk of chemical burns, fires, toxic fumes, and even explosions. In fact, about twenty percent of all labs are found as a result of a fire or explosion. Environmentally, meth production creates large quantities of toxic materials. Specifically, producing one pound of meth creates five pounds of hazardous waste. The production at a small, "Mom and Pop," lab is quite small. A normal production cycle produces only one to four ounces of methamphetamine. This is usually only enough for personal use with just enough left over to sell to purchase the precursors for another cycle. Large labs (which are usually limited to Mexico or California) can produce a minimum of ten pounds per production cycle (Scott, n.d.).

When a laboratory is seized, the governmental officials are responsible for neutralizing the immediate threats to public safety, such as the risk of explosion or chemical contamination of the environment. In many cases, this includes a period of evacuation of the neighborhood

\footnotetext{
${ }^{3}$ Specifically, cold remedies that include ephedrine or pseudoephedrine are now kept behind pharmacist's counters and require the names and license numbers of purchasers to be recorded when making a large purchase.

${ }^{4}$ Based on statistics published by the U.S. drug enforcement agency on their website, http://www.usdoj.gov/dea/concern/map_lab_seizures.html.
} 
until the scene is surveyed and the largest risks are neutralized. The period of evacuation usually ranges from as little as a few hours to as much as a couple of days. Any nonflammable hazardous contaminants in the interior of the building are often the responsibility of the property owner rather than government officials. Specifically, toxic residue may be present on the walls, floors and other surfaces as well as absorbed in any carpeting. About twenty states mandate the decontamination of the interior of former meth homes before it can be sold or rented (Dewan and Brown, 2009). ${ }^{5}$ No definitive conclusions have been drawn by public health and environmental impact experts about the short and long run threats the residual contaminants may pose. Once a laboratory is discovered, it is included in a national registry (discussed below) and in many individual state registries. This implies that home buyers can find information about meth lab locations before purchasing a home.

There are some external signs that may alert neighbors to the existence of a methamphetamine laboratory. The most pronounced sign is odor (Partnership for a Drug Free America, 2005). Meth labs are associated with unusually strong smells similar to ammonia, cat urine, or nail polish. Additionally, neighbors may notice excessive amounts of trash and signs of chemical dumping in a yard. Other warning indicators, such as specific apparatuses and interior markings, can be easily hidden from neighbors. Though there is not data on how labs are usually discovered, anecdotal evidence suggests that most are discovered not because of neighbors' suspicions, but when government officials are investigating complaints unrelated to the drug production such as domestic disturbances or child welfare concerns (Crissey, 2004). The uncertainty over when neighbors become aware of the meth lab complicates the interpretation of the results in this study. Though not suggested anecdotally or in the specification check below, if neighbors do know about the lab before the police, one might expect housing prices to fall before the lab is found and thus mute the observed impact of the lab's discovery by police. If that is the case, the results presented below would be lower

\footnotetext{
${ }^{5}$ Ohio is not one of the states that have such a mandate (Armon, 2009). That said, the state does require a home seller to disclosure the "presence of hazardous materials," specifically asking "Do you know of the previous or current presence of any of the below identified hazardous materials?" Included in the list is an item for "Other toxic or hazardous substances" (Ohio Department of Commerce, 2008).
} 
bounds on the real impact of the discovery of a methamphetamine lab in a neighborhood.

\section{The Data}

This study will examine the impact of methamphetamine laboratory discoveries using data from Summit County, Ohio. This county has been selected because it contains the city of Akron which has the largest number of methamphetamine laboratory discoveries in the state and one of the largest in the country. The laboratory discoveries occur in a broad range of geographical locations which provide a diverse and large sample of homes that are within a quarter of a mile of a discovered meth laboratory. It is not clear how the relative frequency of methamphetamine labs in Akron might effect the generalizability of the findings in this study. I suspect that it may dampen the magnitude of the measured effects as both the community becomes desensitized to this type of crime and as the number of alternatives diminishes.

Data on meth laboratory seizures comes from the United States Drug Enforcement Agency (DEA) maintained "National Clandestine Laboratory Register," though entries rely on reports from state and local officials. ${ }^{6}$ The registry includes the address and seizure date, but not details about the seizure. Local officials determine whether a site is a clandestine laboratory, but presumably homes would need to have equipment associated with meth production (though the site may be active or inactive at the time of discovery). This registry is freely accessible to the public on the Internet and gives home buyers an easy reference to consult before purchasing a home. Real estate sales and dwelling data come from the Summit County Fiscal Office and were made available for this project. These records include the sale price, the transaction date, and the address of the home. Also available from this office are dwelling characteristics such as the square footage of the living area, the age of the structure, number of bedrooms, number of plumbing fixtures, number of stories, the style of the home,

\footnotetext{
${ }^{6}$ http://www.usdoj.gov/dea/seizures/index.html
} 
and a rating of the condition of the building. ${ }^{7}$ The distance between each home sold and the clandestine laboratories has been computed using Geographic Information Systems (GIS) software and geocoded street data from the Ohio Department of Transportation.

Table 1 presents the number of sales and the number of unique parcels used for this study. This study will examine home sales beginning in January 2002 and running through March 2009. The earlier date represents two years before the first meth lab in the dataset is discovered. The sample used here excludes non-single family homes, homes whose sale price is in the top or bottom one percent, and homes missing the full set of dwelling data. Limiting the sample to single family homes is traditional in this literature. Sales in the top and bottom one percent are eliminated to exclude outliers which can skew the results. The number of homes missing a full set of dwelling data is less than one-tenth of one percent. At various points in the analysis, the sample will be limited to different subsets of this data. In total, there are 80,293 home sales in Summit County that were successfully geocoded for use with GIS in the full period of study. Among these sales there are 56,197 unique parcels.

After an initial analysis with the entire dataset, the sample will be reduced to include just those homes within a quarter of a mile of a discovered methamphetamine laboratory and sales within one or two years of each lab's discovery. As shown in Table 1, the bulk of the homes sold are not within a quarter mile of any labs. That said, 12,293 sales are within a quarter mile of at least one past or future laboratory. Amongst those, 3,623 sales occur within one year of the discovery and 7,079 within two years. I make three further sample restrictions. First, all sales within the first 30 days of a lab's discovery are excluded. Second, I exclude sales that are within a quarter mile of more than one laboratory in the period of examination (one or two years) due to the difficulty in parsing out the various effects the discovery of multiple labs might have on the sale price of a home. Later, I will use a second lab's discovery to measure the response to the degree of severity of the perceived level of crime. Finally, I exclude the sales of any homes listed as meth labs to be certain that these

${ }^{7}$ Some of this data is also available at the Fiscal Office's website,
http://www.co.summit.oh.us/fiscaloffice/defaultwebapps.htm


sales are not driving the results. The resulting examination sample includes 2,807 within one year and 4932 within two years of a lab's discovery. The number of sales after the discovery of a lab are fewer than those before due to the omission of the first 30 days following the lab's discovery.

The DEA's registry lists 101 clandestine laboratory sites for the period from January 2004 through July 2007. Just over 25 labs were discovered in each of 2004, 2005, and 2006. Through July of 2007, 21 labs had been discovered. This pattern is slightly different from the national trend which showed a peak in clandestine laboratory discoveries in 2003 and 2004 .

\section{Graphical Evidence}

If there is a negative impact of the discovery of a methamphetamine laboratory on local home prices, one would expect there to be effects in two dimensions: time since the discovery and distance from the lab. In the figures that follow, this paper will present evidence that there is an effect in both dimensions even when looking at raw sales prices. Figure 1 presents the pattern of nominal home prices in the two years before and after a methamphetamine laboratory's discovery. The home price trends for homes within one-eighth of a mile and between one-eighth and one-fourth of a mile are relatively similar before the lab is discovered (negative values on the $\mathrm{x}$-axis). After the lab is discovered (positive values on the $\mathrm{x}$-axis), the trends temporarily diverge until coming back together after about 400 days. The price drop is particularly dramatic at the time of discovery for homes within an eighth of a mile of the discovered lab.

To examine the pattern in sales prices based on the distance from the methamphetamine laboratory, Figure 2 presents the nominal sales price by distance from the discovered laboratory in the year before and after the discovery. Though sales prices are everywhere lower after the lab is discovered than before, the largest gap occurs amongst those homes that are 
closest. The impact of a methamphetamine lab's discovery appears to be largest for those homes within an eighth of a mile (1.25 tenths of a mile on the x-axis). The two groups converge and run parallel at about two-tenths of a mile from the meth lab.

Despite the clear differences by distance from the discovered lab in Figures 1 and 2, the confidence intervals (not shown) for the price trends in both figures are everywhere overlapping and are not statistically different. In the next two sections, I will explore whether this continues to be true once other price determinants are controlled for such as home characteristics (living area; age; number of bedrooms, plumbing fixtures, and stories; condition; and home style), general time trends, and the location of the homes.

\section{$5 \quad$ Empirical Methodology}

Rosen (1974) hedonic price models have been widely used to analyze the value that individuals put on neighborhood qualities, including the quality of education (e.g. Black (1999)), crime (Teh (2007)), and environmental amenities (Davis (2004), Chay and Greenstone (2005), and Greenstone and Gallagher (2008)). Much of the early research examining the impact of crime focused on cross-sectional differences in property values. These studies have the potential problem of omitted variable bias related to neighborhood qualities that are not observed by the researcher and may be correlated with both the characteristic being studied and property values. More recently, research has focused on alternative identification strategies that minimize the concerns over omitted variable bias. Specifically, recent

work (e.g. Linden and Rockoff (2008) and Pope (2008)) has attempted to address the concern that cross-sectional comparisons of different neighborhoods with potential unobserved differences cannot be controlled for in a traditional hedonic home price model. This study will build on this literature by utilizing the discovery of a methamphetamine laboratory as a quasi-random event to explore the impact of the perceived increase in the risk of crime on local home values. 
For this analysis, I will employ a difference-in-difference approach comparing changes to similar areas before and after an event. Specifically, I will compare sale prices for homes in the same neighborhood but at varying distances from a discovered methamphetamine laboratory. By narrowly defining the neighborhood area, I hope to limit any divergent, unobserved differences that may be driving the varying trends in the treated and the comparison groups that may be unrelated to the lab's discovery. The following analysis will include indicators for those properties that are very close to the address of the discovered lab (defined initially as within an eighth of a mile) and those who are slightly farther away (between an eighth and a quarter of a mile). Though discretized distance identifiers are used in the primary analysis, other specifications will include linear and quadratic distance terms to examine patterns within these distance categories.

Table 2 compares the mean values of observable qualities of all sold homes in Summit County to those homes sold within a quarter mile of a past or future meth lab, as well as for homes in the two comparison groups within a quarter mile in the year prior to a lab's discovery. As shown in the first set of columns, the characteristics and sale prices of homes within a quarter mile of a discovered meth lab are very different from homes not within a quarter mile of a lab. The presented t-statistics show that the mean values for the sales price and each characteristic are significantly different across groups at the one percent level. Specifically, homes not near a discovered lab sold for over double the price or homes within a quarter mile of a lab. Additionally, homes more than a quarter mile from the nearest discovered methamphetamine laboratory are significantly larger, are younger, have more bedrooms and bathrooms, are more likely to be a single floor, and are more often rated as in "average" to "excellent" condition than those homes closer to a lab.

The second set of columns in Table 2 examines the differences between the pre-discovery home sale prices of homes that are "close" to the discovered laboratory and those that are "slightly farther" away in the year prior to a lab's discovery. As the t-statistics show, the two groups are very similar. Home sale prices and many of the characteristics are not significantly 
different at the ten percent level. At the ten percent level, homes between one-eighth and one-quarter of a mile from the discovered lab are significantly smaller, are more likely to be one story (and thus more likely to be a ranch style), and less likely to be a colonial style home than those homes within one-eighth of a mile. Otherwise, homes in the two groups are not significantly different.

The analysis of this paper will focus on two primary specifications, similar to the estimation framework of Linden and Rockoff (2008). The differences between the two specifications reflects a difference in the sample being used. The first specification examines all single-family home sales in Summit County, Ohio and uses all homes not within a quarter mile of any methamphetamine labs as the comparison group. The second specification limits the sample to only homes within a quarter mile of the meth lab, and the comparison group includes homes between an eighth of a mile and a quarter of a mile sold before the lab is discovered. The specifications can be represented as follows:

$$
\begin{gathered}
\log \left(P_{i}\right)=\theta_{0}+\beta \mathrm{X}_{i}+\left(\theta_{1} \mathrm{D}_{i}^{\frac{1}{8} \mathrm{th}}+\theta_{2} \mathrm{D}_{i}^{\frac{1}{4} \mathrm{th}}\right)+\left(\theta_{3} \mathrm{D}_{i}^{\frac{1}{8} \text { th }}+\theta_{4} \mathrm{D}_{i}^{\frac{1}{4} \mathrm{th}}\right) * \operatorname{Post}_{i}+\varepsilon_{i} \\
\log \left(P_{i}\right)=\pi_{0}+\gamma \mathrm{X}_{i}+\pi_{1} \mathrm{D}_{i}^{\frac{1}{8} \mathrm{th}}+\left(\pi_{2} \mathrm{D}_{i}^{\frac{1}{8} \mathrm{th}}+\pi_{3} \mathrm{D}_{i}^{\frac{1}{4} \mathrm{th}}\right) * \text { Post }_{i}+\varepsilon_{i}
\end{gathered}
$$

where $\log \left(P_{i}\right)$ is the $\log$ of price for each sale $i{ }^{8} \mathrm{X}$ is a series of home characteristics including age, square footage, number of bedrooms, number of plumbing fixtures, number of stories, condition of the dwelling, locational controls (zip code or dummy identifying which lab the home is within a quarter mile of) and a monthly time trend; $\mathrm{D}_{i}^{\frac{1}{8} \text { th }}$ is an indicator for a home within an eighth of a mile of a past or future methamphetamine laboratory and $\mathrm{D}_{i}^{\frac{1}{4} \text { th }}$ is an indicator for a home that is within a quarter of a mile; and Post $_{i}$ is an indicator for whether the home was sold after the nearby meth lab was discovered. The definition of

\footnotetext{
${ }^{8}$ In past studies, the Consumer Price Index has been used to adjust home prices, but I have instead included a monthly trend variable that should capture price trends in the data. Using a home price index to normalize prices has no substantive effects on the results presented below.
} 
the $\mathrm{D}_{i}$ indicators allows for a simple difference-in-difference interpretation of the results. The coefficients and standard errors of $\theta_{3}$ and $\pi_{2}$ represent the additional change in the home values for those nearest to the meth home after its discovery compared to those who are slightly farther away. The coefficients $\theta_{1}, \theta_{2}$, and $\pi_{1}$ represent any underlying price differences for those homes within certain distances of the methamphetamine lab. If I have appropriately picked our comparison group to be otherwise similar to the treated group, $\theta_{1}$ and $\pi_{1}$ should be zero.

\section{Empirical Results}

As a first step, Table 3 presents the results of the analysis using both sales within a quarter mile of a discovered methamphetamine laboratory and those further away. I employ specification (1) for the results in columns [1] and [2]. Because each parcel may have idiosyncrasies not captured in the dwelling characteristic data, all regression analysis below will cluster the robust standard errors at the parcel level. Column [1] presents the results if all home sales not within a quarter of a mile of any future discovered labs and those sales within both a quarter of a mile and one year of a discovered lab are included. Column [2] widens the temporal window around the methamphetamine lab discovery to two years. As suggested in Table 2, sale prices for those homes within a quarter of a mile of a discovered laboratory are lower than those of the rest of the sample before the lab is discovered. Prices are 5.9 to 6.8 percent lower within a quarter mile of the future lab and even lower after the lab is discovered (though only significantly so in the two year window of column [2]). For those homes that are also within an eighth of a mile of the laboratory, there is no significant difference in the prices relative to the quarter mile group before the discovery (i.e. $\theta_{1}$ is not significantly different from zero) which supports the latter's use as a control group for the former. Counter to the graphical evidence provided above, the coefficient on the eighth of a mile and after the lab's discovery indicator is negative but not significant at traditional 
levels. This suggests that the indicators for within one-fourth of a mile capture most of the impact of the lab's presence. That said, the coefficients of other home characteristics must reflect the whole county in this specification and any differences in how these characteristics are valued in areas around the meth lab will be captured in these distance indicators (full output from these specification can be found in Appendix Table 1).

To limit the issue of differences in the hedonic valuations of characteristics in Summit County as a whole and in the areas around meth labs, columns [3] and [4] of Table 3 examine only homes sold within a quarter of a mile from the lab site, based on specification (2). To control for differences in different regions, dummies are included at the meth lab level (i.e. all home sales within a quarter mile of a discovered meth lab share the same indicator). Again, the analysis is done both with a one and two year window around each laboratory's discovery date. The small magnitude and lack of statistical significance of the coefficient on the term identifying homes within an eighth of a mile $\left(\pi_{1}\right)$ show that the control and experimental groups are not substantively different before the meth lab is discovered. For homes sold less than one year after the laboratory's discovery, there is a 4.5 percent decline in sale prices within a quarter of a mile of the lab and an additional 10.5 percent decline for homes also within an eighth of a mile, which is significantly different from zero at the five percent level. When the window around each meth lab's discovery is extended to two years, the difference-in-difference estimate for the eighth of a mile group is reduced to a decline of 5.6 percent and to no effect for the control group.

When comparing one and two year windows around the discovery of a methamphetamine laboratory, the different magnitudes presented above suggest that the impact of that discovery decreases with time. When examining the timing of the impact of a discovery on home sale prices, Table 4 presents two approaches. In the column [1], the number of months since the meth lab's discovery is included, as is its squared value. In the second approach, the post-discovery indicator is parsed into quarters (i.e. 91 day intervals) since the lab's discovery (columns [2]). The results in column [1] reflects the pattern found in Figure 1 and shows 
that the difference between the two groups is significant once other factors are controlled for. Specifically, the price gap expands initially but at a declining rate for each month after the lab is discovered. The coefficients suggest that the negative effect of the lab's discovery peaks in the ninth month and dissipates by the eighteenth month. Here, there is no significant pattern for those between an eighth and a quarter of a mile from the lab nor when using the second approach in column [2] of Table 4. For homes that are within an eighth of a mile, there is a large and statistically significant, negative impact on home prices between six and 12 months after the labs discovery with prices over 15 percentage points lower in those quarters. The next quarter (366 to 456 days) continues to have a negative coefficient but it no longer is significant. Together, the above results suggest a similar period of recovery for home prices after the termination of perceived crime risk as was found by Pope (2008). Pope found that home prices close to the former location of a sex offender returned to the same level as those homes that were slightly farther away in the year following the sex offender's departure.

The next question to be addressed is how the impact of a discovered lab changes with intensity. Intensity will be measured in two ways: as the presence of an additional lab and as the distance from the discovered lab. The effect of a second laboratory being discovered within an eighth of a mile of the first discovered laboratory is examined in Table 5. Note that the sample has been expanded to include sales within an eighth of a mile of two or more discovered labs in the time period of examination. An indicator for whether a home is sold within an eighth of a mile and after the second lab has been discovered has been added to specification (2). The results for the pre-discovery and post-first discovery identifiers are largely unchanged from the earlier results in columns [3] and [4] of Table 3. The coefficient on the newly added post-second discovery indicator shows that there is not a significantly negative impact of the discovery of a second laboratory. This result suggests that the discovery of a meth lab in a neighborhood has a negative effect that is not changed by additional labs. The result is again similar to the findings of Pope (2008) who found that there was not 
a significant difference in the impact of a sex offender's entry into a neighborhood based on the degree of the entrant's offense (identified as a simple offender or a "predator"). Since the negative impact of a meth labs discovery appears to be a binary effect rather than a level of degree, the discovery may be acting simply as a negative stigma for a neighborhood or area rather than an evaluation of actual health and safety risk.

If the negative impact of the discovery of a methamphetamine lab were a reaction to perceived risk rather than a stigma, one would expect those closest to the lab to be most negatively effected since they would have the highest risk. To consider the distance dimension of impact variation, Table 6 takes a different approach than those summarized in specifications (1) and (2). Specifically, Table 6 reports the coefficient on distance and its squared value (measured in tenths of a mile) before and after the lab is discovered. For consistency, the sample is limited to only homes within one quarter of a mile of the discovered lab and results are presenting for both a one and two year window around the lab's discovery. The coefficients on the distance variable and its squared value show no significant pattern when distance variables are not interacted with the timing of the lab's discovery. After the lab is discovered, there is a significant pattern in the one year window (column [1]) but not once the window is widened to two years. This is not surprising given the timing of the effects found in Table 4. In the one year window, there is a large negative impact for those closest to the discovered lab that increases for about the first one ninth of a mile (0.11 miles). After the first ninth of a mile, the negative effect lessens until reaching zero at about two ninths of a mile.

The pattern found in column [1] of Table 6 suggests that there might be a bigger impact on the price of homes that are not adjacent to the lab itself but are slightly farther away. To examine this question more directly, Table 7 uses a specification similar to specification 2 but with smaller distance increments. Specifically, Table 7 shows the results if home sales within a quarter mile of the discovered are divided by sixteenths of a mile rather than eighths. The results confirm those suggested by the results in Table 6: the price of homes very close to 
the discovered meth lab are not as negatively impacted as those slightly farther away. In fact, the results in Table 7 suggest that the impact on those within one sixteenth of a mile of discovered meth lab is not significantly statistically significant while those homes between one-sixteenth and two-sixteenths of a mile have a large and significantly negative impact from the lab's discovery.

It is an odd finding that those homes sold closest to a discovered methamphetamine lab do not see the biggest negative impact from its discovery. One potential reason is that those closest to the lab actually are aware of its existence before the police discover and shutdown the lab, while those slightly farther away are unaware of the lab until it is discovered by authorities. If that is the case, home values near the lab may fall before the lab is discovered and thus the impact of the official discovery will be muted. To test this possibility, the analysis presented above is repeated with the date of the methamphetamine laboratory's discovery falsely set to one year earlier than the actual date. In order not to overlap with the impact of the true event, the analysis examines only the year before and after the false discovery date. If there is an impact from the existence of the lab before it is discovered, we should expect for home prices to fall in the year before the lab is discovered when compared to two years before the lab is discovered.

Table 8 presents the empirical results using Specification 2 with the labs discovery date moved forward 365 days. Column [1] shows the results when the unit of distance is oneeighth of a mile and shows no significant difference in sales prices between one and two years before the lab is discovered. To examine more closely the differences within an eighth of a mile, Column [2] presents the evidence with the more narrowly defined distance ranges. There is again no significant difference in the home prices between one and two years of the labs official discovery for either those within one sixteenth of a mile from the lab or those between one sixteenth and two sixteenths of a mile. These results show that information before the lab's discovery is not driving the pattern of impact found in Tables 6 and 7 .

A second possible cause for the impact pattern is in the mobility of those who own homes 
around the discovered meth lab. Figure 3 shows the number of monthly sales in the two year period before and after the lab's discovery by the distance from the lab. In the 24 months before the lab is discovered, the sales volume is relatively constant in all four groups. In the months following the lab's discovery, only those between one and two sixteenths of a mile show an immediate and consistent increase in the number of sales. This pattern suggests that home sales prices are being driven down for homes between one and two sixteenths of a mile from the lab due to a rush to market. There could be many reasons for this. Maybe owners of those homes are more sensitive to neighborhood quality than those closer to the discovered lab. Maybe those closest to the lab do not sell their homes because of a recognition of the impact the discovered lab will have on their sales price, thus actually keeping the price relatively high for those who do sell. Finally, maybe those closest to the lab get some offsetting benefit from the labs discovery (like increased police patrols for example) that offset the negative stigma of the lab while the homes slightly farther away only get the stigma effect.

\section{Conclusion}

By assuming that methamphetamine producers locate approximately at random within narrowly defined neighborhoods, this study has been able to employ hedonic estimation methods to estimate the impact of the meth laboratory's discovery on the home values near its location. I find a ten to sixteen percent decline in home values for those near the lab site after it is discovered relative to the value of homes slightly farther away which presumably have similar unmeasured neighborhood attributes. As with the findings in other studies, this finding suggests that individuals are willing to pay a large amount of money to avoid being near the site of a defunct meth laboratory, and by extension to avoid areas associated with prior crime. Additionally, the findings here support previous research (Pope, 2008) that the negative impact of perceived risk of crime is binary and not a matter of degrees since the 
discovery of a second laboratory does not have an amplifying effect on the negative impact and the effect of distance from the lab is not monotonic. From a policy perspective, this finding suggests that government initiatives that would reduce the number of methamphetamine labs should be well funded. 


\section{References}

Armon, Rick, "Meth Labs Spawn Cleanup Industry in Ohio," Associated Press News Wire, August 26, 2009.

Black, Sandra E, "Do Better Schools Matter? Parental Valuation of Elementary Education," Quarterly Journal of Economics, 1999, 114, 577-599.

Chay, Kenneth and Michael Greenstone, "The Impact of Air Pollution on Infant Mortality: Evidence from Geographic Variation in Pollution Shocks Induced by a Recession," Quarterly Journal of Economics, 2005, pp. 1121-1167.

Crissey, M, "Business Cleans Up Meth Labs after Police Finish Their Work," Associated Press News Wire, March 8, 2004.

Cullen, Julie B and Steven D Levitt, "Crime, Urban Flight, and the Consequences for Cities," Review of Economics and Statistics, 1999, 81 (2), 159-169.

Davis, Lucas W, "The Effect of Health Risk on Housing Values: Evidence from Cancer Clusters," American Economic Review, 2004, 94 (5), 1693-1704.

Dewan, Shaila and Robbie Brown, "Illnesses Afflict Homes With a Criminal Past," The New York Times, July 13, 2009.

Dobkin, Carlos and Nancy Nicosia, "The War on Drugs: Methamphetamine, Public Health, and Crime," American Economic Review, 2009, 99 (1), 324-49.

Gibbons, Steve, "The Costs of Urban Property Crime," Economic Journal, 2004, 114 (499), F441-463.

Greenstone, Michael and Justin Gallagher, "Does Hazardous Waste Matter? Evidence from the Housing Market and Superfund Program," Working Paper 149.05, Fondazione Eni Enrico Mattei (FEEM) 2008.

Katz, Lawrence F, Jeffrey R Kling, and Jeffrey B Liebman, "Moving to Opportunity in Boston: Early Results of a Randomized Mobility Experiment," Quarterly Journal of Economics, 2001, 116, 607-654.

Kuziemko, Ilyana and Steven D Levitt, "An Empirical Analysis of Imprisoning Drug Offenders," Journal of Public Economics, 2004, 88, 2043-2066.

Linden, Leigh and Jonah E Rockoff, "Estimates of the Impact of Crime Risk on Property Values from Megan's Laws," American Economic Review, 2008, 98 (3), 1103-1127.

Ohio Department of Commerce, "Residential Property Disclosure Form," 2008.

Partnership for a Drug Free America, "Meth Frequently Asked Questions," 2005. Available at http://www.drugfree.org/Portal/DrugIssue/MethResources/meth_faq.html\#4. 
Pope, Jaren C., "Fear of Crime and Housing Prices: Household Reactions to Sex Offender Registries," Journal of Urban Economics, 2008, 64 (3), 601-614.

Rosen, Sherwin, "Hedonic Prices and Implicit Markets: Product Differentiation in Pure Competition," Journal of Political Economy, 1974, 82 (1), 34-55.

Scott, Michael S., "Clandestine Drug Labs," Problem-Oriented Guides for Police, U.S. Department of Justice. Available at http://www.cops.usdoj.gov/pdf/e02021446.pdf.

Teh, Bing-ru, "Do Liquor Stores Increase Crime and Urban Decay? Evidence from Los Angeles," Dissertation, University of California, Berkeley 2007.

Thaler, Richard, "A Note on the Value of Crime Control: Evidence from the Property Market," Journal of Urban Economics, 1978, 5 (1), 137-145. 
Figure 1: Home Sales Prices by Days since Lab's Discovery

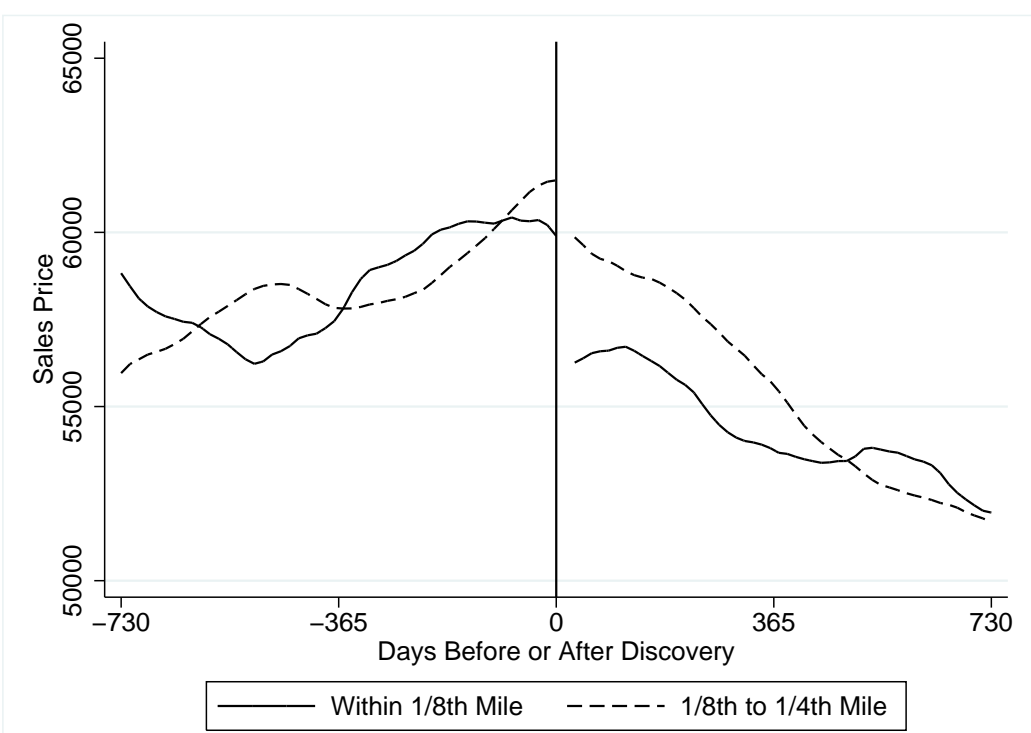

Note: Lines are local polynomial smooth plot for homes sold within two years of discovery using a 90 day bandwidth. 
Figure 2: Home Sales Prices by Distance from Discovered Lab

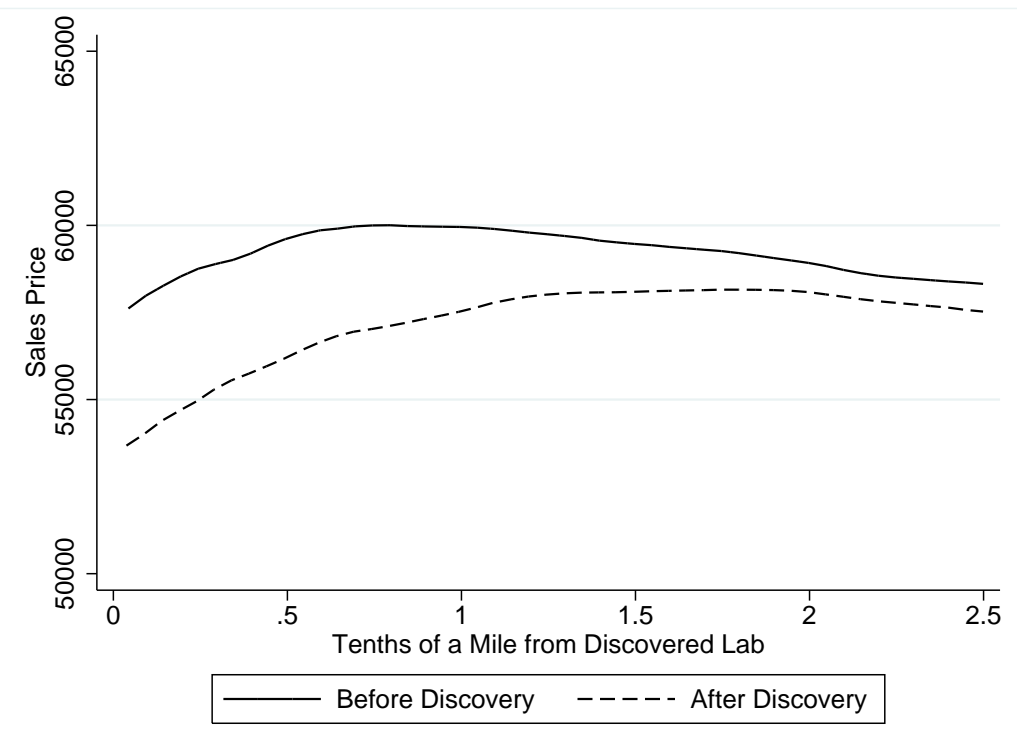

Note: Lines are local polynomial smooth plot for homes sold within one year of discovery using a 0.05 mile bandwidth. 
Figure 3: Number of Sales per Month by Distance
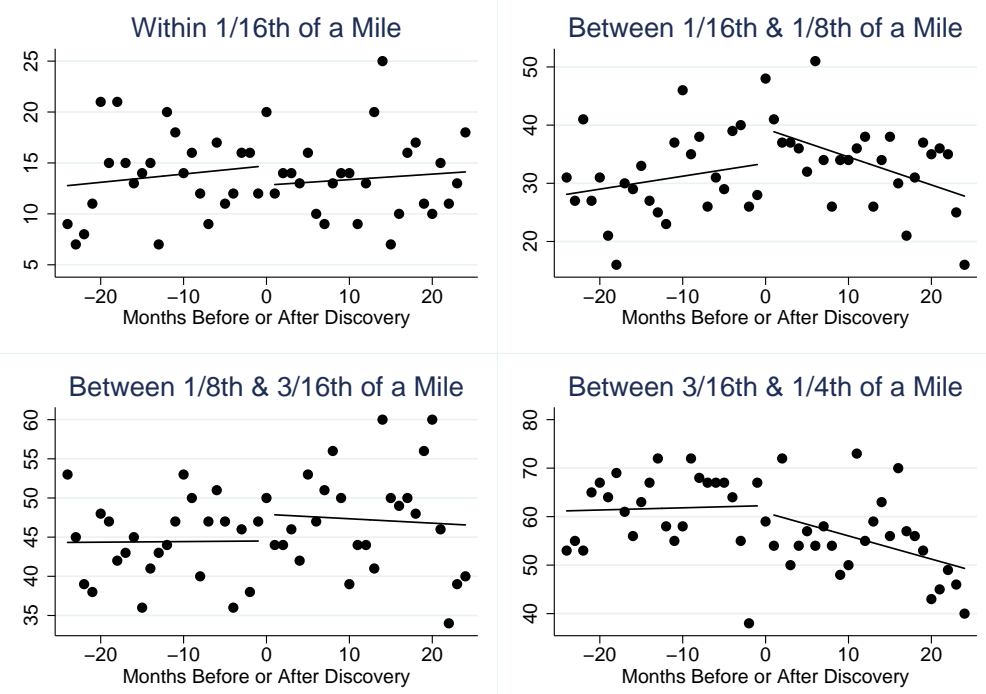

Note: Figures include separate lines of best fit before and after the methamphetamine laboratory is discovered. 
Table 1

Sample of Summit County Home Sales

\begin{tabular}{lccc}
\hline & No labs & \multicolumn{2}{c}{ Lab discovered within 1/4th mile } \\
\cline { 3 - 4 } & within & Sales within one & Sales within two \\
& $1 / 4$ th mile & year of discovery & years of discovery \\
\hline Total number of single-family home sales & 68000 & \multicolumn{2}{c}{12293} \\
Number of unique parcels & 48713 & \multicolumn{2}{c}{7484} \\
Number of sales within examination period & & 3623 & 7079 \\
Less those sold in 30 days following discover & $(170)$ & $(170)$ \\
Less those with 2nd discovery in the period & $(634)$ & $(20)$ \\
Less sales of lab itself & $(12)$ & 4932 \\
Examination sample & 2807 & 2380 \\
Number after discovery & & 1325 & \\
\hline
\end{tabular}

Note: Excludes non-single family homes, homes whose sale price is in the top or bottom 1\%, and homes missing a full set of dwelling data 
Table 2

Comparing Home Characteristics

\begin{tabular}{|c|c|c|c|c|c|c|}
\hline & \multicolumn{3}{|c|}{ Full evaluation period } & \multicolumn{3}{|c|}{$\underline{\text { One year before lab's discovery }}$} \\
\hline & $\begin{array}{c}\text { No labs } \\
\text { discovered }\end{array}$ & $\begin{array}{l}\text { Within } 1 / 4 \text { th } \\
\text { mile of a lab }\end{array}$ & t-stat & $\begin{array}{l}\text { Within } 1 / 8 \text { th } \\
\text { mile of a lab }\end{array}$ & $\begin{array}{l}\text { Between } 1 / 8 \text { th and } \\
1 / 4 \text { th mile of a lab }\end{array}$ & t-stat \\
\hline Nominal sales price & $\$ 131127$ & $\$ 54667$ & $91.09^{* * *}$ & $\$ 59750$ & $\$ 58699$ & -0.57 \\
\hline Square footage of living area & 1698.4 & 1245.1 & $63.12^{* * *}$ & 1297.4 & 1261.1 & $-1.71^{*}$ \\
\hline Age of home & 44.81 & 75.64 & $100.2^{* * *}$ & 76.32 & 74.14 & -1.59 \\
\hline Number of bedrooms & 3.12 & 2.92 & $27.26^{* * *}$ & 2.96 & 2.99 & 0.63 \\
\hline Number of plumbing fixtures & 7.55 & 5.83 & $73.61^{* * *}$ & 5.96 & 5.86 & -1.12 \\
\hline Home is more than 1 story & $47.7 \%$ & $59.1 \%$ & $-23.42^{* * *}$ & $66.4 \%$ & $58.0 \%$ & $-3.01^{* * *}$ \\
\hline Condition of home rated 'fair' or 'poor' & $6.3 \%$ & $17.8 \%$ & $-43.43^{* * *}$ & $18.4 \%$ & $16.3 \%$ & -0.99 \\
\hline Style: Unidentified & $2.6 \%$ & $6.5 \%$ & $-22.56^{* * *}$ & $5.8 \%$ & $5.7 \%$ & -0.09 \\
\hline Style: Colonial & $44.4 \%$ & $53.7 \%$ & $-19.05^{* * *}$ & $60.1 \%$ & $52.8 \%$ & $-2.59 * * *$ \\
\hline Style: Ranch & $28.8 \%$ & $19.0 \%$ & $-22.53^{* * *}$ & $16.6 \%$ & $20.7 \%$ & $1.85^{*}$ \\
\hline Style: Bungalow & $4.0 \%$ & $9.3 \%$ & $-25.11^{* * *}$ & $7.4 \%$ & $9.2 \%$ & 1.13 \\
\hline Style: Cape Cod & $12.1 \%$ & $9.4 \%$ & $8.56^{* * *}$ & $6.7 \%$ & $9.0 \%$ & 1.46 \\
\hline Style: Other & $8.1 \%$ & $2.1 \%$ & $23.52^{* * *}$ & $3.4 \%$ & $2.5 \%$ & -0.91 \\
\hline Number of sales & 68000 & 12293 & & 446 & 1032 & \\
\hline
\end{tabular}

* significant at $10 \% ;{ }^{* *}$ significant at $5 \%$; *** significant at $1 \%$

Note: Excludes non-single family homes, homes whose sale price is in the top or bottom $1 \%$, and homes missing a full set of dwelling data 
Table 3

Estimation of Primary Specifications

\begin{tabular}{|c|c|c|c|c|}
\hline & {$[1]$} & {$[2]$} & {$[3]$} & {$[4]$} \\
\hline & \multicolumn{2}{|c|}{ Full sample } & \multicolumn{2}{|c|}{ Homes within $1 / 4$ th mile of lab } \\
\hline & $\begin{array}{l}\text { Sales within } 1 \\
\text { year of any } \\
\text { lab's discovery }\end{array}$ & $\begin{array}{l}\text { Sales within } 2 \\
\text { years of any } \\
\text { lab's discovery }\end{array}$ & $\begin{array}{l}\text { Sales within } 1 \\
\text { year of each } \\
\text { lab's discovery }\end{array}$ & $\begin{array}{l}\text { Sales within } 2 \\
\text { years of each } \\
\text { lab's discovery }\end{array}$ \\
\hline $\begin{array}{l}\text { Within } 1 / 8 \mathrm{th} \text { of a mile }(660 \mathrm{ft}) \\
\text { of first meth lab discovery }\end{array}$ & $\begin{array}{c}0.021 \\
{[0.034]}\end{array}$ & $\begin{array}{l}0.008 \\
{[0.027]}\end{array}$ & $\begin{array}{c}0.028 \\
{[0.032]}\end{array}$ & $\begin{array}{c}0 \\
{[0.024]}\end{array}$ \\
\hline $\begin{array}{l}\text { Within } 1 / 8 \text { th of a mile and } \\
\text { post-discovery }\end{array}$ & $\begin{array}{l}-0.076 \\
{[0.051]}\end{array}$ & $\begin{array}{l}-0.044 \\
{[0.039]}\end{array}$ & $\begin{array}{c}-0.105^{* *} \\
{[0.047]}\end{array}$ & $\begin{array}{r}-0.056 \\
{[0.035]}\end{array}$ \\
\hline $\begin{array}{l}\text { Within } 1 / 4 \text { th of a mile }(1320 \mathrm{ft}) \\
\text { of first meth lab discovery }\end{array}$ & $\begin{array}{c}-0.059 * * * \\
{[0.019]}\end{array}$ & $\begin{array}{c}-0.068^{* * *} \\
{[0.015]}\end{array}$ & & \\
\hline $\begin{array}{l}\text { Within } 1 / 4 \text { th of a mile and } \\
\text { post-discovery }\end{array}$ & $\begin{array}{l}-0.026 \\
{[0.027]}\end{array}$ & $\begin{array}{c}-0.053^{* *} \\
{[0.021]}\end{array}$ & $\begin{array}{l}-0.045 \\
{[0.049]}\end{array}$ & $\begin{array}{r}-0.008 \\
{[0.037]}\end{array}$ \\
\hline \multicolumn{5}{|l|}{ Other included variables: } \\
\hline Home characteristics & $\mathrm{x}$ & $\mathrm{x}$ & $\mathrm{x}$ & $\mathrm{x}$ \\
\hline Calender month-year & $\mathrm{x}$ & $\mathrm{x}$ & $\mathrm{x}$ & $\mathrm{x}$ \\
\hline Zip code dummies & $\mathrm{x}$ & $\mathrm{x}$ & & \\
\hline Specific laboratory dummies & & & $\mathrm{x}$ & $\mathrm{x}$ \\
\hline Observations & 56555 & 72948 & 2807 & 4932 \\
\hline R-squared & 0.54 & 0.55 & 0.39 & 0.39 \\
\hline
\end{tabular}

Standard errors in brackets. ${ }^{*}$ significant at $10 \% ;{ }^{* *}$ significant at $5 \% ;{ }^{* * *}$ significant at $1 \%$

Note: Robust standard errors clustered at the parcel level

Note: Excludes non-single family homes, homes whose sale price is in the top or bottom 1\%, and homes missing a full set of dwelling data 
Table 4

Analysis using Time since Meth Lab Discovery

\begin{tabular}{|c|c|c|}
\hline & $\begin{array}{l}{[1]} \\
\text { Time in months }\end{array}$ & $\begin{array}{c}{[2]} \\
\text { Time in quarters }\end{array}$ \\
\hline $\begin{array}{l}\text { Within } 1 / 8 \mathrm{th} \text { of a mile }(660 \mathrm{ft}) \\
\text { of first meth lab discovery }\end{array}$ & $\begin{array}{l}-0.003 \\
{[0.023]}\end{array}$ & $\begin{array}{c}0 \\
{[0.024]}\end{array}$ \\
\hline $\begin{array}{l}\text { Months since discovery ( } 1=30 \text { days }) \\
\text { if } \mathrm{w} / \mathrm{n} 1 / 8 \text { mile of meth lab }\end{array}$ & $\begin{array}{c}-0.018^{* *} \\
{[0.009]}\end{array}$ & \\
\hline $\begin{array}{l}\text { Square of Months since Discovery } \\
(1=30 \text { days }) \text { if } w / n 1 / 8 \text { mile }\end{array}$ & $\begin{array}{l}0.001^{*} \\
{[0.000]}\end{array}$ & \\
\hline $\begin{array}{l}\text { Home is } \mathrm{w} / \mathrm{n} 1 / 8 \text { mile of lab } \\
\text { and } \mathrm{w} / \mathrm{n} 91 \text { days after discovery }\end{array}$ & & $\begin{array}{r}-0.063 \\
{[0.079]}\end{array}$ \\
\hline $\begin{array}{l}\text { Home is w/n } 1 / 8 \text { mile of lab and } \\
\text { b/w } 92 \& 182 \text { days after discovery }\end{array}$ & & $\begin{array}{r}0.013 \\
{[0.071]}\end{array}$ \\
\hline $\begin{array}{l}\text { Home is w/n } 1 / 8 \text { mile of lab and } \\
\text { b/w } 183 \& 273 \text { days after discovery }\end{array}$ & & $\begin{array}{l}-0.149^{* *} \\
{[0.072]}\end{array}$ \\
\hline $\begin{array}{l}\text { Home is w/n } 1 / 8 \text { mile of lab and } \\
\text { b/w } 274 \& 365 \text { days after discovery }\end{array}$ & & $\begin{array}{l}-0.195^{* *} \\
{[0.079]}\end{array}$ \\
\hline $\begin{array}{l}\text { Home is w/n } 1 / 8 \text { mile of } 1 \text { st lab and } \\
\text { b/w } 366 \& 456 \text { days after discovery }\end{array}$ & & $\begin{array}{r}-0.049 \\
{[0.073]}\end{array}$ \\
\hline $\begin{array}{l}\text { Home is w/n } 1 / 8 \text { mile of } 1 \text { st lab and } \\
\text { b/w } 457 \& 547 \text { days after discovery }\end{array}$ & & $\begin{array}{r}0.041 \\
{[0.076]}\end{array}$ \\
\hline $\begin{array}{l}\text { Home is w/n } 1 / 8 \text { mile of } 1 \text { st lab and } \\
\text { b/w } 548 \& 638 \text { days after discovery }\end{array}$ & & $\begin{array}{r}-0.082 \\
{[0.076]}\end{array}$ \\
\hline $\begin{array}{l}\text { Home is w/n } 1 / 8 \text { mile of } 1 \text { st lab and } \\
\text { b/w } 639 \& 730 \text { days after discovery }\end{array}$ & & $\begin{array}{r}0.064 \\
{[0.082]}\end{array}$ \\
\hline $\begin{array}{l}\text { Months since discovery ( } 1=30 \text { days }) \\
\text { if } \mathrm{w} / \mathrm{n} 1 / 4 \text { mile of meth lab }\end{array}$ & $\begin{array}{l}0.005 \\
{[0.007]}\end{array}$ & \\
\hline $\begin{array}{l}\text { Square of Months since discovery } \\
\text { if } \mathrm{w} / \mathrm{n} 1 / 4 \text { mile of meth lab }\end{array}$ & $\begin{array}{c}0 \\
{[0.000]}\end{array}$ & \\
\hline $\begin{array}{l}\text { Home is } \mathrm{w} / \mathrm{n} 1 / 4 \text { mile of lab and } \\
\mathrm{w} / \mathrm{n} 91 \text { days after discovery }\end{array}$ & & $\begin{array}{r}-0.012 \\
{[0.053]}\end{array}$ \\
\hline $\begin{array}{l}\text { Home is w/n } 1 / 4 \text { mile of lab and } \\
\text { b/w } 92 \& 182 \text { days after discovery }\end{array}$ & & $\begin{array}{r}-0.048 \\
{[0.053]}\end{array}$ \\
\hline $\begin{array}{l}\text { Home is w/n } 1 / 4 \text { mile of lab and } \\
\text { b/w } 183 \& 273 \text { days after discovery }\end{array}$ & & $\begin{array}{r}0.002 \\
{[0.052]}\end{array}$ \\
\hline $\begin{array}{l}\text { Home is w/n } 1 / 4 \text { mile of lab and } \\
\text { b/w } 274 \& 365 \text { days after discovery }\end{array}$ & & $\begin{array}{c}0.05 \\
{[0.060]}\end{array}$ \\
\hline $\begin{array}{l}\text { Home is w/n } 1 / 4 \text { mile of lab and } \\
\text { b/w } 366 \& 456 \text { days after discovery }\end{array}$ & & $\begin{array}{r}-0.053 \\
{[0.064]}\end{array}$ \\
\hline $\begin{array}{l}\text { Home is w/n } 1 / 4 \text { mile of lab and } \\
\text { b/w } 457 \& 547 \text { days after discovery }\end{array}$ & & {$\left[\begin{array}{c}0 \\
{[0.068}\end{array}\right]$} \\
\hline $\begin{array}{l}\text { Home is w/n } 1 / 4 \text { mile of lab and } \\
\text { b/w } 548 \& 638 \text { days after discovery }\end{array}$ & & $\begin{array}{r}-0.059 \\
{[0.072]}\end{array}$ \\
\hline $\begin{array}{l}\text { Home is w/n } 1 / 4 \text { mile of lab and } \\
\text { b/w } 639 \& 730 \text { days after discovery }\end{array}$ & & $\begin{array}{r}-0.108 \\
{[0.077]}\end{array}$ \\
\hline \multicolumn{3}{|l|}{ Other included variables: } \\
\hline Home characteristics & $\mathrm{x}$ & $\mathrm{x}$ \\
\hline Calender month-year dummies & $\mathrm{x}$ & $\mathrm{x}$ \\
\hline Specific laboratory dummies & $\mathrm{x}$ & $\mathrm{x}$ \\
\hline Observations & 4932 & 4932 \\
\hline R-squared & 0.39 & 0.4 \\
\hline
\end{tabular}


Table 5

Analysis using Second Lab Discovery in Period of Examination

\begin{tabular}{lcc}
\hline & $\begin{array}{c}1 \\
\text { Sales within 1 year } \\
\text { of lab's discovery }\end{array}$ & $\begin{array}{c}2 \\
\text { Sales within 2 years } \\
\text { of lab's discovery }\end{array}$ \\
\hline Within 1/8th of a mile (660 ft) of & 0.024 & 0.003 \\
at least one meth lab discovery & {$[0.031]$} & {$[0.023]$} \\
Within 1/8th of a mile and after & $-0.109^{* *}$ & $-0.063^{*}$ \\
at least one lab discovery & {$[0.045]$} & {$[0.033]$} \\
Within 1/8th of a two labs and & 0.067 & 0.056 \\
after a second lab is discovered & {$[0.083]$} & {$[0.055]$} \\
Within 1/4th of a mile and after & -0.048 & -0.005 \\
at least one lab discovery & {$[0.048]$} & {$[0.036]$} \\
Other included variables: & & $\mathrm{x}$ \\
Home characteristics & $\mathrm{x}$ & $\mathrm{x}$ \\
Calender month-year dummies & $\mathrm{x}$ & $\mathrm{x}$ \\
Specific laboratory dummies & 2928 & 0.39 \\
\hline Observations & 0.39 & \\
R-squared & & \\
\hline Standard errors in brackets. ${ }^{*}$ significant at $10 \% ; *$ significant at $5 \% ; * *$ sig- \\
nificant at 1\% \\
Note: Robust standard errors clustered at the parcel level \\
Note: Excludes non-single family homes, homes whose sale price is in the top or \\
bottom 1\%, and homes missing a full set of dwelling data
\end{tabular}


Table 6

Analysis by Linear Distance from Meth Lab Site

\begin{tabular}{|c|c|c|}
\hline & $\begin{array}{l}{[1]} \\
\text { Sales within } 1 \text { year } \\
\text { of lab's discovery }\end{array}$ & $\begin{array}{l}{[2]} \\
\text { Sales within } 2 \text { years } \\
\text { of lab's discovery }\end{array}$ \\
\hline $\begin{array}{l}\text { Distance from discovered } \\
\text { lab }(1=.1 \text { miles })\end{array}$ & $\begin{array}{c}0.133 \\
{[0.090]}\end{array}$ & $\begin{array}{r}0.076 \\
{[0.068]}\end{array}$ \\
\hline $\begin{array}{l}\text { Squared distance from } \\
\text { discovered lab }\end{array}$ & $\begin{array}{l}-0.045 \\
{[0.032]}\end{array}$ & $\begin{array}{r}-0.021 \\
{[0.024]}\end{array}$ \\
\hline $\begin{array}{l}\text { Distance from lab and } \\
\text { after lab's discovery }\end{array}$ & $\begin{array}{c}-0.162^{* *} \\
{[0.080]}\end{array}$ & $\begin{array}{r}-0.031 \\
{[0.062]}\end{array}$ \\
\hline $\begin{array}{l}\text { Squared distance from lab and } \\
\text { after lab's discovery }\end{array}$ & $\begin{array}{c}0.070^{* *} \\
{[0.033]}\end{array}$ & $\begin{array}{r}0.014 \\
{[0.026]}\end{array}$ \\
\hline $\begin{array}{l}\text { Other included variables: } \\
\text { Home characteristics } \\
\text { Calender month-year dummies } \\
\text { Specific laboratory dummies }\end{array}$ & $\begin{array}{l}\mathrm{x} \\
\mathrm{x} \\
\mathrm{x}\end{array}$ & $\begin{array}{l}\mathrm{x} \\
\mathrm{x} \\
\mathrm{x}\end{array}$ \\
\hline $\begin{array}{l}\text { Observations } \\
\text { R-squared }\end{array}$ & $\begin{array}{l}2807 \\
0.39\end{array}$ & $\begin{array}{l}4932 \\
0.39\end{array}$ \\
\hline \multicolumn{3}{|c|}{$\begin{array}{l}\text { Standard errors in brackets. }{ }^{*} \text { significant at } 10 \% ;{ }^{* *} \text { significant at } 5 \% ;{ }^{* * *} \text { significant } \\
\text { at } 1 \% \\
\text { Note: Robust standard errors clustered at the parcel level } \\
\text { Note: Excludes non-single family homes, homes whose sale price is in the top or bottom } \\
1 \% \text {, and homes missing a full set of dwelling data }\end{array}$} \\
\hline
\end{tabular}


Table 7

Analysis by Incremental Distance from Meth Lab Site

\begin{tabular}{lcc}
\hline & $\begin{array}{c}{[1]} \\
\text { Sales within 1 year } \\
\text { of lab's discovery }\end{array}$ & $\begin{array}{c}{[2]} \\
\text { Sales within 2 years } \\
\text { of lab's discovery }\end{array}$ \\
\hline Within 1/16th mile (330 ft) & -0.022 & -0.032 \\
of discovered lab & {$[0.049]$} & {$[0.037]$} \\
Within 1/16th mile (330 ft) of discovered & -0.052 & -0.015 \\
lab and after discovery & {$[0.089]$} & {$[0.064]$} \\
Within 2nd 1/16th mile (330 to $660 \mathrm{ft})$ & 0.057 & 0.016 \\
of discovered lab & {$[0.041]$} & {$[0.030]$} \\
Within 2nd 1/16th mile $(330$ to $660 \mathrm{ft})$ & $-0.190^{* * *}$ & $-0.085^{*}$ \\
of discovered lab and after discovery & {$[0.060]$} & {$[0.046]$} \\
Within 3rd 1/16th mile $(660$ to $990 \mathrm{ft})$ & 0.01 & 0.001 \\
of discovered lab & {$[0.035]$} & {$[0.026]$} \\
Within 3rd 1/16th mile $(660$ to $990 \mathrm{ft})$ & -0.078 & -0.014 \\
of discovered lab and after discovery & {$[0.058]$} & {$[0.044]$} \\
Within 4th 1/16th mile $(990$ to $1320 \mathrm{ft})$ & -0.017 & -0.003 \\
of discovered lab and after discovery & {$[0.053]$} & {$[0.040]$} \\
Other included variables: & & $\mathrm{x}$ \\
Home characteristics & $\mathrm{x}$ & $\mathrm{x}$ \\
Calender month-year dummies & $\mathrm{x}$ & $\mathrm{x}$ \\
Specific laboratory dummies & 2807 & 0.39 \\
\hline Observations & 0.39 & 4932 \\
R-squared & $\mathrm{x}$ &
\end{tabular}

Standard errors in brackets. ${ }^{*}$ significant at $10 \% ;{ }^{* *}$ significant at $5 \% ;{ }^{* *}$ significant at $1 \%$

Note: Robust standard errors clustered at the parcel level

Note: Excludes non-single family homes, homes whose sale price is in the top or bottom $1 \%$, and homes missing a full set of dwelling data 
Table 8

Analysis Using a False Date (One Year Earlier) of Lab's Discovery

\begin{tabular}{|c|c|c|}
\hline & \multicolumn{2}{|c|}{$\begin{array}{l}\text { Sales within } 1 \text { year of } \\
\text { false lab discovery }\end{array}$} \\
\hline $\begin{array}{l}\text { Within } 1 / 8 \text { th of a mile }(660 \mathrm{ft}) \text { of } \\
\text { first meth lab discovery }\end{array}$ & $\begin{array}{l}-0.005 \\
{[0.032]}\end{array}$ & \\
\hline $\begin{array}{l}\text { Within } 1 / 8 \text { th of a mile and } \\
\text { after false discovery }\end{array}$ & $\begin{array}{c}0.028 \\
{[0.044]}\end{array}$ & \\
\hline $\begin{array}{l}\text { Within } 1 / 16 \text { th mile }(330 \mathrm{ft}) \text { of } \\
\text { discovered lab }\end{array}$ & & $\begin{array}{r}-0.012 \\
{[0.049]}\end{array}$ \\
\hline $\begin{array}{l}\text { Within } 1 / 16 \mathrm{th} \text { mile }(330 \mathrm{ft}) \text { of } \\
\text { discovered lab and after false discovery }\end{array}$ & & $\begin{array}{r}-0.034 \\
{[0.066]}\end{array}$ \\
\hline $\begin{array}{l}\text { Within } 2 \text { nd } 1 / 16 \text { th mile }(330 \text { to } 660 \mathrm{ft}) \text { of } \\
\text { discovered lab }\end{array}$ & & $\begin{array}{r}-0.003 \\
{[0.040]}\end{array}$ \\
\hline $\begin{array}{l}\text { Within } 2 \text { nd } 1 / 16 \text { th mile ( } 330 \text { to } 660 \mathrm{ft} \text { ) of } \\
\text { discovered lab and after false discovery }\end{array}$ & & $\begin{array}{r}0.049 \\
{[0.061]}\end{array}$ \\
\hline $\begin{array}{l}\text { Within } 1 / 4 \text { th of a mile and } \\
\text { after false discovery }\end{array}$ & $\begin{array}{l}-0.007 \\
{[0.042]}\end{array}$ & \\
\hline $\begin{array}{l}\text { Within 3rd 1/16th mile (660 to } 990 \mathrm{ft} \text { ) of } \\
\text { discovered lab }\end{array}$ & & $\begin{array}{r}-0.002 \\
{[0.035]}\end{array}$ \\
\hline $\begin{array}{l}\text { Within 3rd 1/16th mile (660 to } 990 \mathrm{ft} \text { ) of } \\
\text { discovered lab and after false discovery }\end{array}$ & & $\begin{array}{r}0.001 \\
{[0.052]}\end{array}$ \\
\hline $\begin{array}{l}\text { Within } 4 \text { th } 1 / 16 \text { th mile (990 to } 1320 \mathrm{ft} \text { ) of } \\
\text { discovered lab and after false discovery }\end{array}$ & & $\begin{array}{c}-0.01 \\
{[0.045]}\end{array}$ \\
\hline Other included variables: & & \\
\hline Home characteristics & $\mathrm{x}$ & $\mathrm{x}$ \\
\hline Calender month-year dummies & $\mathrm{x}$ & $\mathrm{x}$ \\
\hline Specific laboratory dummies & $\mathrm{x}$ & $\mathrm{x}$ \\
\hline Observations & 2863 & 2863 \\
\hline R-squared & 0.42 & 0.42 \\
\hline
\end{tabular}

Standard errors in brackets. ${ }^{*}$ significant at $10 \%$;* significant at $5 \%$; $* * *$ significant at $1 \%$

Note: Robust standard errors clustered at the parcel level

Note: Excludes non-single family homes, homes whose sale price is in the top or bottom $1 \%$, and homes missing a full set of dwelling data 
Appendix Table 1

Estimation of Primary Specifications, Full Results

\begin{tabular}{|c|c|c|c|c|}
\hline & {$[1]$} & {$[2]$} & \multirow{2}{*}{\multicolumn{2}{|c|}{$\begin{array}{c}{[3]} \\
\text { Homes within } 1 / 4 \text { th mile of lab }\end{array}$}} \\
\hline & \multicolumn{2}{|c|}{ Full sample } & & \\
\hline & Within 1 year & Within 2 years & Within 1 year & Within 2 years \\
\hline $\begin{array}{l}\text { Within } 1 / 8 \mathrm{th} \text { of a mile }(660 \mathrm{ft}) \\
\text { of first meth lab discovery }\end{array}$ & $\begin{array}{l}0.021 \\
{[0.034]}\end{array}$ & $\begin{array}{c}0.008 \\
{[0.027]}\end{array}$ & $\begin{array}{l}0.028 \\
{[0.032]}\end{array}$ & $\begin{array}{c}0 \\
{[0.024]}\end{array}$ \\
\hline $\begin{array}{l}\text { Within } 1 / 8 \text { th of a mile and } \\
\text { post-discovery }\end{array}$ & $\begin{array}{l}-0.076 \\
{[0.051]}\end{array}$ & $\begin{array}{l}-0.044 \\
{[0.039]}\end{array}$ & $\begin{array}{c}-0.105^{* *} \\
{[0.047]}\end{array}$ & $\begin{array}{r}-0.056 \\
{[0.035]}\end{array}$ \\
\hline $\begin{array}{l}\text { Within 1/4th of a mile }(1320 \mathrm{ft}) \\
\text { of first meth lab discovery }\end{array}$ & $\begin{array}{c}-0.059^{* * *} \\
{[0.019]}\end{array}$ & $\begin{array}{c}-0.068^{* * *} \\
{[0.015]}\end{array}$ & & \\
\hline $\begin{array}{l}\text { Within } 1 / 4 \text { th of a mile and } \\
\text { post-discovery }\end{array}$ & $\begin{array}{l}-0.026 \\
{[0.027]}\end{array}$ & $\begin{array}{c}-0.053^{* *} \\
{[0.021]}\end{array}$ & $\begin{array}{l}-0.045 \\
{[0.049]}\end{array}$ & $\begin{array}{r}-0.008 \\
{[0.037]}\end{array}$ \\
\hline Square footage of living area & $\begin{array}{c}0.130^{* * *} \\
{[0.007]}\end{array}$ & $\begin{array}{c}0.142^{* * *} \\
{[0.006]}\end{array}$ & $\begin{array}{c}0.290^{* * *} \\
{[0.049]}\end{array}$ & $\begin{array}{l}0.321^{* * *} \\
{[0.033]}\end{array}$ \\
\hline $\begin{array}{l}\text { Age of home (in } 10 \text { year } \\
\text { increments) }\end{array}$ & $\begin{array}{c}-0.027^{* * *} \\
{[0.001]}\end{array}$ & $\begin{array}{c}-0.028^{* * *} \\
{[0.001]}\end{array}$ & $\begin{array}{c}-0.044^{* * *} \\
{[0.009]}\end{array}$ & $\begin{array}{c}-0.051^{* * *} \\
{[0.006]}\end{array}$ \\
\hline Number of bedrooms & $\begin{array}{c}0.046^{* * *} \\
{[0.005]}\end{array}$ & $\begin{array}{c}0.043^{* * *} \\
{[0.004]}\end{array}$ & $\begin{array}{c}0.045^{* *} \\
{[0.018]}\end{array}$ & $\begin{array}{l}0.028^{* *} \\
{[0.013]}\end{array}$ \\
\hline Number of plumbing fixtures & $\begin{array}{c}0.029 * * * \\
{[0.002]}\end{array}$ & $\begin{array}{c}0.028^{* * *} \\
{[0.002]}\end{array}$ & $\begin{array}{c}0.011 \\
{[0.010]}\end{array}$ & $\begin{array}{c}0.008 \\
{[0.007]}\end{array}$ \\
\hline Home is more than 1 story & $\begin{array}{c}-0.131^{* * *} \\
{[0.019]}\end{array}$ & $\begin{array}{c}-0.133^{* * *} \\
{[0.016]}\end{array}$ & $\begin{array}{c}-0.225^{* * *} \\
{[0.080]}\end{array}$ & $\begin{array}{l}-0.160^{* * *} \\
{[0.051]}\end{array}$ \\
\hline $\begin{array}{l}\text { Condition of home is rated } \\
\text { as 'Fair' or 'Poor' }\end{array}$ & $\begin{array}{c}-0.372^{* * *} \\
{[0.011]}\end{array}$ & $\begin{array}{c}-0.365^{* * *} \\
{[0.010]}\end{array}$ & $\begin{array}{c}-0.180^{* * *} \\
{[0.033]}\end{array}$ & $\begin{array}{l}-0.163^{* * *} \\
{[0.023]}\end{array}$ \\
\hline Style: Unidentified & $\begin{array}{c}-0.187^{* * *} \\
{[0.019]}\end{array}$ & $\begin{array}{c}-0.179^{* * *} \\
{[0.016]}\end{array}$ & $\begin{array}{l}-0.081 \\
{[0.061]}\end{array}$ & $\begin{array}{r}-0.028 \\
{[0.038]}\end{array}$ \\
\hline Style: Ranch & $\begin{array}{c}-0.087^{* * *} \\
{[0.020]}\end{array}$ & $\begin{array}{c}-0.081^{* * *} \\
{[0.017]}\end{array}$ & $\begin{array}{c}-0.166^{* *} \\
{[0.082]}\end{array}$ & $\begin{array}{c}-0.129 * * \\
{[0.054]}\end{array}$ \\
\hline Style: Bungalow & $\begin{array}{c}-0.156^{* * *} \\
{[0.022]}\end{array}$ & $\begin{array}{c}-0.134^{* * *} \\
{[0.020]}\end{array}$ & $\begin{array}{c}-0.152^{*} \\
{[0.085]}\end{array}$ & $\begin{array}{l}-0.063 \\
{[0.057]}\end{array}$ \\
\hline Style: Cape Cod & $\begin{array}{l}-0.029 \\
{[0.020]}\end{array}$ & $\begin{array}{l}-0.026 \\
{[0.017]}\end{array}$ & $\begin{array}{l}-0.091 \\
{[0.084]}\end{array}$ & $\begin{array}{r}-0.039 \\
{[0.056]}\end{array}$ \\
\hline Style: Other & $\begin{array}{l}-0.026 \\
{[0.019]}\end{array}$ & $\begin{array}{c}-0.032^{*} \\
{[0.016]}\end{array}$ & $\begin{array}{l}-0.176 \\
{[0.109]}\end{array}$ & $\begin{array}{c}-0.175^{* *} \\
{[0.071]}\end{array}$ \\
\hline Other included variables: & & & & \\
\hline $\begin{array}{l}\text { Calender month-year dummies } \\
\text { Zip code dummies }\end{array}$ & $\begin{array}{l}\mathrm{x} \\
\mathrm{x}\end{array}$ & $\begin{array}{l}\mathrm{x} \\
\mathrm{x}\end{array}$ & $\mathrm{x}$ & $\mathrm{x}$ \\
\hline Specific laboratory dummies & & & $\mathrm{x}$ & $\mathrm{x}$ \\
\hline Observations & 56555 & 72948 & 2807 & 4932 \\
\hline R-squared & 0.54 & 0.55 & 0.39 & 0.39 \\
\hline
\end{tabular}

Standard errors in brackets. ${ }^{*}$ significant at $10 \% ; * *$ significant at $5 \%$; $* * *$ significant at $1 \%$

Note: Robust standard errors clustered at the parcel level

Note: Excludes non-single family homes, homes whose sale price is in the top or bottom 1\%, and homes missing a full set of dwelling data 